\title{
A INTERCULTURALIDADE COMO POSSIBILIDADE PARA A CONSTRUÇÃO DE UMA VISÃO DE DIREITOS HUMANOS A PARTIR DAS REALIDADES PLURAIS DA AMÉRICA LATINA
}

\section{INTERCULTURALITY AS A POSSIBILITY FOR THE FORMATION OF A HUMAN RIGHTS VIEW FROM THE PLURAL REALITIES OF LATIN AMERICA}

\author{
Fernanda Frizzo Bragato \\ Universidade do Vale do Rio dos Sinos - Unisinos (São Leopoldo, RS, Brasil) \\ Vicente de Paulo Barretto \\ Universidade do Vale do Rio dos Sinos - Unisinos (São Leopoldo, RS, Brasil)
}

Alex Sandro da Silveira Filho

Universidade do Vale do Rio dos Sinos - Unisinos (São Leopoldo, RS, Brasil)

Recebimento: 14 jun. 2016

Aceitação: 17 mar. 2017

\begin{abstract}
Como citar este artigo / How to cite this article (informe a data atual de acesso / inform the current date of access):
BRAGATO, Fernanda Frizzo; BARRETTO, Vicente de Paulo; SILVEIRA FILHO, Alex Sandro da. A interculturalidade como possibilidade para a construção de uma visão de direitos humanos a partir das realidades plurais da América Latina. Revista da Faculdade de Direito UFPR, Curitiba, PR, Brasil, v. 62, n. 1, jan./abr. 2017, p. 33 - 59. ISSN $2236-7284$. Disponível em: <http://revistas.ufpr.br/direito/article/view/47133>. Acesso em: 30 abr. $2017 . \quad$ DOI: http://dx.doi.org/10.5380/rfdufpr.v62i1.47133.
\end{abstract}

\section{RESUMO}

O discurso universalista dos direitos humanos, construído sobre o paradigma liberal-individualista da modernidade, apresenta limitações no que se refere ao reconhecimento e à concepção positiva da humanidade de determinados grupos historicamente inferiorizados, que são alvo de preconceito, de discriminação e de exclusão. O objetivo deste trabalho é apontar a perspectiva da interculturalidade como possibilidade para a construção de uma visão de direitos humanos que parta da realidade sociohistórica de América Latina, caracterizada pela pluralidade de culturas, mas que, todavia, tem menosprezado certos indivíduos e grupos (negros, indígenas, mulheres e homossexuais). Para tal apontamento, faz-se uma análise bibliográfica das bases ideológicas do discurso dominante (ocidental) dos direitos humanos, expondo as insuficiências do multiculturalismo e propondo a interculturalidade. Os resultados finais apontam que a interculturalidade é a saída mais adequada para a efetivação dos direitos humanos na América Latina, pois abarca as realidades plurais que se apresentam na região e enfrenta a lógica hierarquizadora imposta pelo projeto moderno/colonial, elemento que não é enfrentado pelo multiculturalismo.

\section{PALAVRAS-CHAVE}

Direitos humanos. América Latina. Modernidade/colonialidade. Multiculturalismo. Interculturalidade. 


\begin{abstract}
The universal human rights discourse, built on the liberal-individualist paradigm of modernity, has limitations as regards both the recognition and the positive conception of humanity of historically belittled groups, which are subject to prejudice, discrimination and exclusion. This paper aims to point out the interculturalism perspective as a possibility for the formation of a human rights view based on the social and historical reality of Latin America. This reality is characterized by the plurality of cultures, but certain individuals and groups (blacks, the indigenous, women, homosexuals) have been despised. To deal with such concern, a bibliographic analysis of the ideological bases of the Western dominant discourses of human rights will be done, thus exposing the inadequacies of multiculturalism and proposing interculturality. The conclusive results show that interculturalism is the most appropriate way out for the realization of human rights in Latin America, since it covers the plural realities present in the region and faces the hierarchy-based logic imposed by the modern/colonial project, an element that is not faced by multiculturalism.
\end{abstract}

\title{
KEYWORDS
}

Human rights. Latin America. Modernity/coloniality. Multiculturalism. Interculturalism.

\section{INTRODUÇÃO}

O discurso hegemônico de fundamentação dos direitos humanos, surgido no seio da modernidade, fundou uma tradição em que a humanidade do ser humano estaria embasada na sua racionalidade. Porém, dado o contexto colonial no qual esse discurso surgiu, nem todos os seres humanos eram, para a visão europeia, dotados de racionalidade, o que lhes faria menos humanos (ou não humanos) em relação ao europeu conquistador. Por conta disso, tal discurso de fundamentação acabou inferiorizando identidades culturais distintas da europeia ocidental, como as presentes na América Latina, tornando os portadores de tais identidades propensos a sucessivas violações de direitos humanos.

Assim, no escopo do projeto mencionado, este trabalho tem como objetivo geral investigar em que medida a ideia de interculturalidade pode representar uma alternativa ao paradigma liberalindividualista da modernidade, em cujo seio surgiu e se desenvolveu o multiculturalismo, que demonstrou seus limites e insuficiências para traduzir e representar as demandas dos indivíduos e grupos estigmatizados. Como objetivos específicos, a pesquisa em tela tem as seguintes intenções: a) analisar como se caracteriza o contexto latino-americano, para fins do projeto de pesquisa em que esse estudo está inserido, e para o próprio texto em si; b) examinar como surge o discurso dominante dos direitos humanos, suas características principais e como, a partir dele, se desenvolveu a perspectiva do multiculturalismo; e c) estudar a teoria da interculturalidade, bem como o que leva tal perspectiva a ser mais adequada para as realidades plurais da América Latina. Isso porque, conforme 
se verá abaixo, o multiculturalismo defende a diversidade cultural, mas sem sacudir a base individualista da racionalidade moderna, a mesma que produziu a cultura hegemônica ocidental. Assim, essa corrente é insuficiente para abarcar as realidades plurais da América Latina e do Caribe, em que as culturas indígenas, afrodescendentes, europeias, asiáticas, mestiças, etc., convivem há tempos em uma tensão interétnica e/ou inter-racial permanente.

Tal apontamento será feito a partir de uma análise, cindida em três tópicos, dos discursos de direitos humanos, suas concepções e críticas. No primeiro tópico, será analisado o contexto latinoamericano, bem como a influência exercida pela lógica da colonialidade para a geração de assimetrias entre os grupos sociais da América Latina. No segundo tópico, será analisado o discurso tradicional dos direitos humanos, bem como a sua raiz alternativa, o multiculturalismo, que busca lidar com a diversidade das culturas, fazendo uma análise de seus conceitos e suas críticas. No terceiro e último tópico faremos um estudo sobre a interculturalidade, que é alternativa latino-americana, apresentando-a como uma possibilidade para que os indivíduos e grupos estigmatizados da América Latina possam ter seus direitos reconhecidos.

Esta pesquisa, de cunho científico, usa como método de abordagem a metodologia hipotético-dedutiva, pois busca analisar por que a teoria do multiculturalismo não é aplicável para as realidades plurais da América Latina, assim como o que leva a interculturalidade a ser a alternativa teórica mais adequada para a compreensão de tais realidades. Como processo de procedimento, temse o método comparativo, em que as perspectivas teóricas do multiculturalismo e da interculturalidade são colocadas frente a frente, para que possamos analisar qual é a mais adequada para a América Latina. Por fim, como técnica de pesquisa, é utilizada a revisão bibliográfica, em livros e artigos que analisam o contexto latino-americano em que a pesquisa está inserida, o discurso dominante dos direitos humanos, o multiculturalismo e a interculturalidade.

\section{AMÉRICA LATINA NA PERSPECTIVA DA COLONIALIDADE: ASSIMETRIAS E DESIGUALDADES}

O projeto moderno caracterizou-se pela hegemonia da racionalidade ocidental que implicou a dominação política, econômica e cultural dos povos conquistados e/ou colonizados. Na América Latina, essa dominação foi tamanha que criou, em grande medida, um ser humano privado de seus caminhos histórico-culturais, que são pilares na recriação das identidades tanto individuais como coletivas. Alguns intelectuais da região dimensionaram o tamanho desse problema e buscaram apontar a necessidade da construção de uma identidade latino-americana. 
Não obstante, Zea afirma (1970, p. 13) que o “continente latinoamericano” necessita de um projeto de originalidade, isto é, de um projeto que busque o seu reconhecimento e de seus sujeitos frente à cultura ocidental, pois aqui existem outros povos, os povos do continente latino-americano, que também fazem e possuem cultura.

Inicialmente, para que possa se compreender, cumpre trazer a diferença dos processos de subalternização ocorridos na América Latina em relação a outras regiões do globo. Quijano e Wallerstein (1992, p. 583) afirmam que em regiões periféricas do que chamaram de "nova economiamundo capitalista”, como a Sicília e a Polônia, houve condições de resistência por conta da força organizativa das comunidades agrícolas dessas regiões, estando assim capazes de fundar, em sua historicidade, sua resistência cultural aos processos de opressão que ocorreram ao longo desse período. Na América, todavia, os autores afirmam que

hubo una destrucción tan vasta de las poblaciones indígenas y una importación tan abundante de mano de obra, que el proceso de periferización generó menos una reconstrucción de instituciones políticas y económicas, que su construcción, virtualmente ex-nihilo toda-parte (salvo tal vez en las zonas mejicanas y andinas). Incluso, desde el principio, la forma de resistencia cultural a las condiciones opresivas fue menos en términos de historicidad que en términos de un salto hacia la «modernidad» (QUIJANO; WALLERSTEIN, 1992, p. 583)

A esse fenômeno, desenvolvido na modernidade, de subalternização da América Latina, foi dado o nome de americanidade. Essa novidade trazida pelo fenômeno moderno apresenta, para Quijano e Wallerstein (1992, p. 584), quatro elementos centrais: colonialidade, etnicidade, racismo e o próprio conceito de “novidade” em si mesmo. A colonialidade caracterizou-se como uma forma de dominação em todos os níveis - econômico, político, social e cultural -, sendo que as independências não a desfizeram, senão transformaram, sensivelmente, os seus contornos (QUIJANO; WALLERSTEIN, 1992, p. 584-585). A etnicidade se caracteriza como "el conjunto de límites comunales que en parte nos colocan los otros y en parte nos los imponemos nosotros mismos, como forma de definir nuestra identidad y nuestro rango con el estado" (QUIJANO; WALLERSTEIN, 1992, p. 585). Porém, apenas as diferenças impostas pela etnicidade não eram suficientes para manter a superioridade étnica e cultural que os europeus desejavam projetar sobre a América Latina, sobretudo com o fim do colonialismo e dos regimes escravocratas. Por conta disso, surgiu a dimensão racista da colonialidade, que, ainda que já estivesse presente desde os primeiros marcos coloniais, tornou-se um paradigma teórico e até mesmo jurídico a partir do séc. XIX (QUIJANO; WALLERSTEIN, 1992, p. 586). E a reificação da “novidade”, para Quijano e Wallerstein, seria a estratégia retórica de imputar ao sujeito colonizado que tudo aquilo que lhes era apresentado pelos povos europeus era mais novo, mais “moderno”, superior ao que eles tinham - e que, por conta disso 
devia ser descartado, o que aconteceu, por exemplo com o desprezo aos conhecimentos tradicionais em prol da ciência (QUIJANO; WALLERSTEIN, 1992, p. 587).

Ademais, o próprio projeto de constituição do nome América Latina é baseado em um projeto de hegemonia ocidental. De acordo com o semiólogo argentino Walter Mignolo (2007, p. 81), as ideias de "latinidade” ou de “América Latina” devem ser entendidas de forma correlata à história de um imperialismo em ascensão no séc. XIX na Europa (especialmente França e Inglaterra), preocupado, no caso francês, com a ascensão do poder norte-americano. Em ambos os casos, o que estava em jogo era a expansão da economia capitalista. Dissimulando seus interesses reais, o imperialismo francês desde então se impôs como defensor da "cultura latina”, que estava "ameaçada" pela “cultura anglo-saxã” (ARDAO, 1993, p. 15-73). Dessa forma, a América Latina deveria “emancipar-se culturalmente” da América "saxã”. Mignolo critica a apropriação, pela elite latinoamericana, do discurso "emancipador”, deixando claro seu lado obscuro. E enfatiza isso da seguinte maneira:

\begin{abstract}
«América Latina» fue el nombre elegido para denominar la restauración de la «civilización» de la Europa meridional, católica y latina en América del Sur y, al mismo tiempo, reproducir las ausencias (de los indios y los africanos) del primer período colonial. La historia de «América Latina» posterior a la independencia es la historia variopinta de la comunión voluntaria o involuntaria de las élites locales con la «modernidad», que entrañó el empobrecimiento y la marginación de los pueblos indígenas, africanos y mestizos. La «idea» de América Latina es la triste celebración por parte de las élites criollas de su inclusión en la modernidad, cuando en realidad se hundieron cada vez más en la lógica de la colonialidad. (MIGNOLO, 2007, p. 82)
\end{abstract}

Tais processos foram fundamentais para que, sobretudo após a independência da América espanhola, os países recém-formados adquirissem a característica europeia do Estado-Nação, que havia surgido na Revolução Francesa. Isso porque, como aponta González Casanova (2006, p. 197), ainda que as colônias tenham alcançado a independência, como já fora dito, as suas estruturas internacional e interna não perceberam mudanças. Se no âmbito internacional a estrutura não se alterou com a descolonização, no âmbito interno isso ocorreu mediante a manutenção do dualismo colonizador/colonizado presente na colônia bem como um tipo igual de relações, corroboradas pelo até então recém-adotado modelo de Estado-Nação (GONZÁLEZ CASANOVA, 2006, p. 197). Na visão do sociólogo mexicano, essas novas nações, por conservar o dualismo preexistente no período colonial, reforçando as estruturas de poder, deram causa a um fenômeno intitulado colonialismo interno, que se definiria como

una estructura de relaciones sociales de dominio y explotación entre grupos culturales heterogéneos, distintos. Si alguna diferencia específica tiene respecto de otras relaciones de dominio y explotación (ciudad-campo, clases sociales) es la heterogeneidad cultural que 
históricamente produce la conquista de unos pueblos por otros, y que permite hablar no sólo de diferencias culturales (que existen entre la población urbana y rural y en las clases sociales) sino de diferencias de civilización (GONZÁLEZ CASANOVA, 2006, p. 197-198)

Ademais, o colonialismo interno não se confunde com a estruturação marxista da sociedade em classes, pois, de acordo com González Casanova, não é somente uma relação de domínio e exploração dos trabalhadores pelos proprietários dos bens de produção e seus colaboradores, senão uma relação de domínio e exploração de uma população (com suas distintas classes, proprietários e trabalhadores) por outra população que também tem distintas classes (proprietários e trabalhadores), sendo diferenciados pelo papel que ocupam na estrutura colonial das sociedades ditas “pós-coloniais”, como as latino-americanas (GONZÁLEZ CASANOVA, 2006, p. 198).

Como será visto mais adiante, o discurso do multiculturalismo celebra, a partir da perspectiva dos direitos humanos, a heterogeneidade das culturas, mas sem desvelar as relações de poder e de dominação que as atravessam. Desse modo, fica comprovada a vinculação desse discurso ao paradigma liberal-individualista assumido na modernidade europeia.

O surgimento da modernidade, representada pelos diversos avanços econômicos e filosóficos da Europa pós-renascentista, conviveu com a propagação, pelo resto do mundo e em especial na América Latina, da subalternização de todas as formas de exercício do poder, do ser, do pensar e do viver. Daí que a modernidade se tornou a própria expressão da expansão e da projeção da política, economia, conhecimento e cultura europeus como as únicas formas válidas de representação. Isso é, de algum modo, o que Escobar (2003, p. 62) define como eurocentrismo: "el modelo de conocimiento que representa la experiencia histórica local europea, la cual ha devenido globalmente hegemónica desde el siglo XVII”.

O eurocentrismo é um conceito que, em Quijano (2005), expressa a racionalidade específica do novo padrão mundial de poder que se estabeleceu na modernidade por meio das relações coloniais. O eurocentrismo constitui uma perspectiva binária, dualista das relações intersubjetivas e culturais entre a Europa e o resto do mundo codificadas num jogo de categorias (Oriente-Ocidente, primitivocivilizado, mágico/mítico-científico, irracional-racional, tradicional-moderno), que se impôs como mundialmente hegemônica no mesmo fluxo de expansão do domínio colonial da Europa sobre o mundo. Além de ter se tornado uma perspectiva hegemônica de produção de conhecimento, funda-se em dois mitos, segundo os quais a história da civilização humana é uma trajetória linear rumo ao progresso cujo apogeu é a Europa e as diferenças entre Europa e não Europa são naturais e não decorrentes das relações assimétricas de poder (QUIJANO, 2005). 
O eurocentrismo é uma perspectiva de conhecimento que encobre uma visão global de modernidade. Uma visão global questiona a associação da modernidade às ideias de racionalidade, progresso, avanço e ciência e torna visível seu lado obscuro, que é a colonialidade. Para que a colonialidade se tornasse possível, foi fundamental a articulação da categoria de raça, concebida na modernidade $^{1}$, para colocar determinados sujeitos em relação de superioridade em comparação a outros. Conforme assinala Quijano (2005),

A idéia de raça, em seu sentido moderno, não tem história conhecida antes da América. Talvez se tenha originado como referência às diferenças fenotípicas entre conquistadores e conquistados, mas o que importa é que desde muito cedo foi construída como referência a supostas estruturas biológicas diferenciais entre esses grupos. A formação de relações sociais fundadas nessa idéia, produziu na América identidades sociais historicamente novas: índios, negros e mestiços, e redefiniu outras. Assim, termos com espanhol e português, e mais tarde europeu, que até então indicavam apenas procedência geográfica ou país de origem, desde então adquiriram também, em relação às novas identidades, uma conotação racial. E na medida em que as relações sociais que se estavam configurando eram relações de dominação, tais identidades foram associadas às hierarquias, lugares e papéis sociais correspondentes, com constitutivas delas, e, conseqüentemente, ao padrão de dominação que se impunha. Em outras palavras, raça e identidade racial foram estabelecidas como instrumentos de classificação social básica da população.

A passagem anterior mostra que a modernidade teve seu momento fundante na conquista da América e se caracterizou pelas relações de profunda assimetria que produziu, o que afasta a concepção tradicional de que se trata de um fenômeno ocorrido e desenvolvido exclusivamente dentro dos limites espaciais da Europa (DUSSEL, 1994, p. 178, 2015, p. 275-280).Em outras palavras, a colonialidade foi tão importante para a modernidade que, segundo Escobar (2003, p. 61), não poderia existir modernidade sem colonialidade, que é constitutiva da primeira ou a sua face oculta.

Essa colonialidade pode ser classificada em três eixos indissolúveis, quais sejam: a) colonialidade do poder, que, segundo Quijano (2007, p. 93), consiste emum dos elementos

\footnotetext{
${ }^{1}$ Entre os estudiosos de raça e racismo, existe una polêmica interessante que busca responder se o racismo nasce com a modernidade europeia ou não. Dessa polêmica, pode-se localizar três posturas principais: a primeira postura sustenta que, se o racismo surge no Ocidente (Europa e América) com a modernidade europeia (Aníbal Quijano, Peter Wade, Michel Wieviorka, entre outros), é uma postura "nem transhistórica nem transcultural”; a segunda, que é uma postura “transhistórica mas não transcultural”, defende a ideia de que os distintos tipos de racismo que conhecemos hoje vieram à luz no Ocidente; entretanto, sendo um fenômeno que antecede o advento da modernidade europeia (Guy Rozat, Lothar Kanuth); a última postura demonstra que o racismo é um fenômeno natural, já que é parte integrante do comportamento sociocultural ou psicológico (aquele desejo de diferenciar-se do outro, negá-lo, matá-lo) de qualquer ser humano (Cornelius Castoriadis, Lawrence Hirschfeld), sendo esta corrente "transhistórica y transcultural” (GALL, 2007, p. 6388). Tendo em vista essa polêmica e limitando-nos ao propósito deste trabalho, consideramos, seguindo a postura "no transhistórica ni transcultural”, que a conquista das Américas e a escravização dos africanos neste continente foi o momento-chave para entender o racismo atual, visando ter condições de lutar contra ele. Isso porque o sistema escravista estabeleceu relações sociais de dominação e exploração baseadas na raça, isto é, nos fenótipos das pessoas (cor da pele, tipo de cabelo, nariz), colocando, em termos fanonianos, as pessoas de cor da pele branca na "zona do ser”, e as pessoas de cor da pele negra na "zona do não ser".
} 
constitutivos e específicos do padrão mundial de poder capitalista, que se funda na imposição de uma classificação racial/étnica da população do mundo que se origina e se mundializa a partir da conquista da América; b) colonialidade do saber, que na argumentação de Walsh (2008, p. 137), é “el posicionamiento del eurocentrismo como la perspectiva única del conocimiento, la que descarta la existencia y viabilidad de otras racionalidades epistémicas y otros conocimientos que no sean los de los hombres blancos europeos o europeizados”, e c) colonialidade do ser, que, também segundo Walsh (2008, p. 137), refere-se aos processos de inferiorização, subalternização e desumanização oriundos do projeto moderno.

A colonialidade produziu relações de poder profundamente desiguais entre os diferentes grupos identitários na América Latina, criando assimetrias na participação política e na distribuição de recursos disponíveis no espaço público, o que significa a privação de direitos humanos à grande parte dos indígenas, afrodescendentes, mulheres e homossexuais, pois as posições sociais e o acesso ao poder e ao saber são determinados, na modernidade/colonialidade, por questões de raça, etnia e gênero.

Na Europa, a máxima expressão desses males foram o fascismo e o nazismo. Para impedir sua repetição, um instrumento eticamente eficaz foi adotado: a Declaração Universal dos Direitos Humanos (1948). Nessa declaração, estabelece-se como fundamental o princípio da igualdade e dignidade de todos os seres humanos, como seres dotados de razão e consciência. Esse princípio é uma crítica frontal à racionalidade moderna excludente. Tal crítica, no continente americano, possibilitou o surgimento do multiculturalismo, para lidar com o persistente problema de desigualdade socioeconômica e de dominação da cultura hegemônica ocidental.

\section{O MULTICULTURALISMO: UMA ALTERNATIVA OCIDENTAL PARA A UNIVERSALIDADE DOS DIREITOS HUMANOS}

Os antecedentes históricos imediatos dos direitos humanos, no mundo ocidental, podem ser localizados a partir da modernidade iluminista europeia.Os direitos humanos, nessa época, surgiram da necessidade de garantir direitos que são inerentes à própria natureza, como à vida, à liberdade, à segurança e à felicidade, devendo o Estado assegurar a efetivação desses direitos, sem intervir, todavia, na esfera privada de seus sujeitos (BOBBIO, 1998, p. 11). Esse discurso, que mais tarde se tornará dominante, é pautado, segundo Bragato (2009, p. 31), pela virada antropocêntrica que acompanhou o início da modernidade, com a mudança cartesiana que colocou a razão no lugar de 
Deus. Desse modo se produziu um novo paradigma do sujeito racional, mas que não se afastou da cosmovisão cristã, sendo, inclusive, constituído intelectualmente por esta.

Com o despontar do Estado liberal, oriundo das revoluções inglesas, francesas e norteamericanas, que ressaltou a primazia dos indivíduos, os direitos humanos surgiram primeiro como protetores de sua autonomia, o que fez autores como Norberto Bobbio (2004, p. 12) concluírem que o pressuposto do liberalismo são os direitos do homem. Dessa maneira, "existe uma essência universal do homem, que pertence e é atributo de cada indivíduo, e tal essência é o que se compartilha como ser humano e que permite identificar e afirmar a sua superioridade em relação a todos os demais seres” (BRAGATO, 2014, p. 208). Essa superioridade tem como premissa principal o uso da razão. Dito isso, pode-se afirmar que

os direitos naturais do homem nasceram como decorrência da superioridade intrínseca do sujeito racional, que é o centro do modelo antropocêntrico. Convencionou-se, a partir daí, que o conceito de direitos é tanto o fundamento quanto a culminação da visão moral, filosófica e legal da modernidade que a teoria dos direitos humanos teria incorporado. (BRAGATO, 2014, p. 209)

Assim, o discurso universalista moderno dos direitos humanos, calcado sob o paradigma liberal-individualista, projetou as primeiras declarações de direitos, como o Bill of Rights inglês, de 1689, a Declaração de Independência dos Estados Unidos da América, de 1776, a Declaração Francesa dos Direitos do Homem e do Cidadão, de 1789. No século XIX, surgiram e se expandiram ideias cuja aplicação ocultou os direitos humanos: o positivismo e o darwinismo social ${ }^{2}$. As consequências dessas ideias são conhecidas: os crimes contra a humanidade perpetrados pelo colonialismo ocidental, na África e na Ásia; o extermínio de grupos sociais pelos nazistas, etc.

Em seu texto A inversão ideológica dos direitos humanos, Hinkelammert (2003) revela a ideologia por trás da manipulação do discurso dos direitos humanos em prol da afirmação de um poder de matriz colonial. Hinkelammert (2003) defende que há uma inversão na lógica da proteção dos direitos humanos, cujo principal teórico continua sendo John Locke, e que consiste no fato de que esses direitos são destruídos em seu próprio nome. Essa lógica tem uma longa história visível no direito de defesa em guerras consideradas de agressão, no despojo da propriedade dos indígenas americanos e na escravidão:

\footnotetext{
${ }^{2}$ Dessas duas correntes, filosófica e social, construiu-se, entre a segunda metade do séc. XIX e a primeira metade do séc. $\mathrm{XX}$, o racismo científico. Um exemplo desse último é o poligenismo: a ideia de que as "razas eran permanentes, tipos separables de los seres con cualidades innatas que eran transmitidas de generación en generación” (WADE, 1997, p. 10).
} 
Os espanhóis basearam a conquista da América na denúncia dos sacrifícios humanos cometidos pelas civilizações aborígenes da América. Mais tarde, a conquista da América do Norte foi defendida com base nas violações de direitos humanos pelos nativos americanos. A conquista da África foi justificada pela denúncia do canibalismo, a conquista da Índia pela denúncia da imolação das viúvas, a destruição da China pela guerra do ópio foi igualmente baseada na violação de direitos humanos. O ocidente conquistou o mundo, destruiu culturas e civilizações, cometeu genocídios nunca percebidos; e todas essas guerras foram feitas para salvar os direitos humanos. (HINKELAMMERT, 2003)

A Declaração Universal dos Direitos Humanos, de 1948, foi pensada, de certo modo, como uma crítica às ideologias desumanizantes, e foi promulgada para evitar que nunca mais voltassem a ocorrer crimes abomináveis contra o ser humano, intento que ainda se mostra distante. Para tanto, a Declaração reconheceu e decretou o princípio da igualdade e dignidade de todos os seres humanos. O multiculturalismo, no continente americano, retomará as ideias dos direitos humanos para lidar com o problema da convivência, num mesmo Estado, de identidades étnico-culturais e raciais distintas. Mas a própria inversão ideológica dos direitos humanos, que os torna a própria causa de sua destruição quando seus titulares são aqueles que se opõem à lógica liberal-burguesa, mostra em que medida a concepção e a valoração da cultura jogam um papel importante na forma como esses direitos podem ser protegidos e efetivados.

O multiculturalismo, inicialmente, é um discurso que não surge de bases filosóficas, mas de uma tradição antropológica iniciada na primeira metade do séc. XX, principalmente, pelo antropólogo estadunidense de origem judaico-alemã Franz Boas, com a definição de relativismo cultural. Boas, em seu tempo, foi integrante de uma profunda mudança no estudo da antropologia que, inicialmente, trabalhava com relações sujeito-objeto em acordo com a Teoria da Evolução Cultural, até então vigente na época, e que assumiu um tipo de estudo antropológico que permitisse estudar os sujeitos a partir da sua realidade, haja vista os métodos etnocêntricos e a invalidade do determinismo geográfico que a antropologia cultural tinha até então (SEEMANN, 2005, p. 13).

Assim, o antropólogo alemão, ao iniciar seus estudos sobre as culturas, afirmou inicialmente que os fenômenos culturais eram tão complexos que não seria suficientemente confiável e, ao mesmo tempo, seria difícil, encontrar leis culturais válidas; e, por conta disso, os dados antropológicos não poderiam se apresentar como uma fórmula exata, aplicável a todos os casos (SEEMANN, 2005, p. 13-14). Ademais, Seemann (2005, p. 14) afirma que, na visão de Boas, a cultura poderia ser definida como "manifestações de costumes sociais de uma comunidade, as reações dos indivíduos quando atingidos pelos costumes de seu grupo e os produtos das atividades determinadas por esses costumes”. Tais apontamentos foram fundamentais para assinalar, em última análise, que não havia superioridade de uma cultura sobre outra, como apontado pela geração anterior de antropólogos, o que tornou inequívoca a existência de um relativismo cultural. 
Com o aporte antropológico da relativização das culturas proposto por Boas, o debate de como lidar com diferentes realidades chegou até o campo da filosofia, e, sobretudo, de pesquisadoras e pesquisadores da área dos direitos humanos. Assim, começa a se desenvolver o multiculturalismo que, para Andrade (2013, p. 91), enquanto fato, consiste na convivência de vários grupos étnicos num mesmo território, e, enquanto teoria de caráter normativo, se apresenta como uma proposta de resolução dos conflitos entre indivíduos e grupos que coexistem e que buscam manter seus traços culturais e sociais num mesmo território.

Na sua concepção teórica, o multiculturalismo se divide em duas grandes correntes: a comunitarista, que é capitaneada pela política de reconhecimento de Charles Taylor e pela cidadania multicultural de Will Kymlicka, e a corrente liberal, que tem como principal expoente Yves Charles Zarka.

A perspectiva comunitarista do multiculturalismo, conforme Tenfen Silva (2006, p. 314), visa questionar a pressuposição de um sujeito de direitos humanos universal e sem lugar histórico, dando primazia, de tal modo, à "multiplicidade de identidades sociais e culturais étnicas presentes nas sociedades contemporâneas e concebendo a justiça como a virtude na aplicação de regras conforme as especificidades de cada meio ou ambiente social”. Assim, chega-se à política de reconhecimento, que Taylor explica da seguinte maneira:

Alguns aspectos da política actual estimulam a necessidade, ou, por vezes, a exigência, de reconhecimento. Pode-se dizer que a necessidade é, no âmbito da política, uma das forças motrizes dos movimentos nacionalistas. E a exigência faz-se sentir, na política de hoje, de determinadas formas, em nome dos grupos minoritários ou "subalternos", em algumas manifestações do feminismo e naquilo que agora, na política, se designa por "multiculturalismo". (TAYLOR, 1998, p. 45)

Além disso, o filósofo canadense ressalta que o processo de reconhecimento é concomitante com a questão da identidade, sendo esta última "qualquer coisa como a maneira como uma pessoa se define, como é que as suas características fundamentais fazem dela um ser humano” (TAYLOR, 1998, p. 45), pois esta identidade é constituída pela presença ou ausência de reconhecimento, ou até por uma forma errônea de reconhecimento, o que pode levar aquele indivíduo ou grupo a ser alvo de preconceito e discriminação negativa. O pensador coloca, inclusive, que esse reconhecimento se dá em dois níveis: um privado, em que a constituição da identidade é entendida como componente de um diálogo e luta permanentes com os demais sujeitos, e um nível público, em que se deve evitar a existência de cidadãos de “primeira classe” e de "segunda classe” (TAYLOR, 1998, p. 57-58).

Destaca-se, também, que a política de reconhecimento possui duas faces: uma enquanto política de dignidade universal, que busca a igualdade universal entre os sujeitos, e outra enquanto 
política de diferença, em que “exige-se o reconhecimento da identidade única deste ou daquele indivíduo ou grupo, do caracter singular de cada um” (TAYLOR, 1998, p. 58).Para Taylor, a política de reconhecimento só se amolda às bases do Estado liberal, porém, nesta feita, “o Estado adota uma concepção substantiva de bem, levando em conta metas coletivas, primando pela defesa da comunidade e pela diversidade cultural” (TENFEN SILVA, 2006, p. 317-318), sendo um modelo de sociedade liberal em que a “vida boa” será caracterizada pela capacidade de cada cultura de se integrar com a outra (TAYLOR, 1998, p. 77):

Uma sociedade com objectivos colectivos fortes pode ser liberal, segundo esta perspectiva,
desde que seja capaz de respeitar a diversidade, em especial, quando considera aqueles que
não partilham dos objectivos comuns, e desde que possa proporcionar garantias adequadas
para os direitos fundamentais. Concretizar todos estes objectivos irá provocar, sem dúvida,
tensões e dificuldades, mas não é nada de impossível, e os problemas não são, em princípio,
maiores do que aqueles que qualquer sociedade liberal encontra quando tem de combinar,
por exemplo, liberdade com igualdade ou prosperidade com justiça. (TAYLOR, 1998, p. 78)

A outra teoria comunitarista do multiculturalismo, capitaneada pelo também canadense Will Kymlicka, tem como objetivo expor as diferenças que determinados tipos de minorias têm, e que direitos poderiam ter reconhecidos (KYMLICKA, 2010, p. 25). Inicialmente, o autor faz uma distinção entre Estados multinacionais e Estados poliétnicos. Os Estados multinacionais seriam espaços de coexistência entre mais de uma nação, aqui entendida como "una comunidad histórica, más o menos completa institucionalmente, que ocupa un territorio o una tierra natal determinada y que comparte una lengua y una cultura diferenciadas” (KYMLICKA, 2010, p. 26).

A coexistência pode ter se estabelecido, de forma voluntária, se as nações tiveram interesse em formar uma federação, por exemplo; ou involuntária, em caso de invasão, conquista ou cessão daquele território, bem como acontece com os povos originários, por exemplo. Os Estados poliétnicos, por outro lado, são constituídos por nações coexistentes por meio da imigração, em que esses grupos (aqui chamados de grupos étnicos) pleiteiam integrar-se na sociedade da qual são parte e serem aceitos como membros de pleno direito (KYMLICKA, 2010, p. 26).

Will Kymlicka atem-se, em sua teoria de reconhecimento, ao multiculturalismo que deriva de diferenças nacionais ou étnicas, não abrangendo, assim, outros grupos vulnerabilizados, como mulheres, gays, lésbicas e deficientes, não porque as demandas desses grupos não sejam relevantes, mas sim porque transcendem os limites dos Estados multinacionais e poliétnicos; afinal, se reconhecidas as diferenças culturais dos grupos étnicos e das nações, poder-se-á buscar o reconhecimento das demandas desses outros grupos (KYMLICKA, 2010, p. 37).

Dada essa delimitação, o filósofo canadense apresenta três formas de direitos diferenciados em função do grupo ou nação em que se encontrem, quais sejam: a) políticas de autogoverno, que 
consistem na reinvindicação, por parte dos grupos, de autonomia política ou jurisdição territorial, de acordo com o que prevê o art. $1^{\circ}$ da Carta da ONU, ressaltando o problema da falta da definição de “povo” que existe nesse artigo, o que levou os Estados a reconhecerem a autodeterminação somente para colônias ultramarinas, e não para suas minorias nacionais internas (KYMLICKA, 2010, p. 4748); b) direitos poliétnicos, que tem como objetivo “ayudar a los grupos étnicos y a las minorías religiosas a que expresen su particularidad y su orgullo cultural sin que ello obstaculice su éxito en las instituciones económicas y políticas de la sociedad dominante” (KYMLICKA, 2010, p. 53), e c) direitos especiais de representação, que consistem em assegurar a participação efetiva dos grupos e nações no processo político e nos espaços de poder, por meio de ações afirmativas (KYMLICKA, 2010, p. 54).

No tocante à crítica feita ao Estado liberal, por não ser adequado para assegurar direitos a grupos e nações, por seu enfoque no indivíduo, Kymlicka acredita que a crítica é inadequada, pois uma das funções precípuas dos direitos individuais é justamente contribuir para a manutenção de uma ampla gama de relações sociais (2010, p. 46). Assim, “a moralidade política liberal apresenta boas razões para justificar o reconhecimento público da pertença cultural e não exclui o valor das práticas e relações sociais e culturais; apenas lhes atribui um outro significado” (WERLE; COSTA, 1997, p. 162).

Numa perspectiva puramente liberal do multiculturalismo, encontra-se na obra de Yves Charles Zarka as principais bases para sua defesa, fazendo-se, inicialmente, uma pesada crítica ao pensamento de Taylor e Kymlicka:

\begin{abstract}
as respostas (a questão da diversidade cultural) trazidas a essas questões [...] pelos defensores da cidadania multicultural, como Will Kymlicka ou mesmo Charles Taylor, me parecem por completo insuficientes porque reduzem a democracia aos procedimentos para admitir as diferenças culturais (concepções de bens) ditas razoáveis, mas ficamos sem saber como resolver o irrazoável, o extremista e a violência, pois são essas situações que destroem o conceito universal de cidadania e ameaçam a democracia ao fazê-la aceitar práticas ou modos que sejam contrários aos seus princípios fundamentais. (ZARKA, 2013, p. 12)
\end{abstract}

Assim, Zarka impõe a tolerância como instrumento central do multiculturalismo, mas reconhece a dificuldade de sua adoção frente à coexistência de culturas e à falta de reciprocidade, que seria o elemento fundamental para o seu reconhecimento (2013, p. 37). Para o professor francês, as opressões, injustiças sociais e explorações que ocorrem no mundo o tornam “despedaçado” (ZARKA, 2013, p. 47), o que desvincula o reconhecimento de uma reconciliação, fundando a legitimidade das diferenças, sem permitir que se transformem em oposições ou enfrentamentos (ZARKA, 2013, p. 64).

Zarka refuta o reconhecimento de características intrínsecas de determinados grupos culturais, pois não vê problema em valores como dignidade, igualdade e liberdade terem sido 
construídos no Ocidente e serem universalizados como princípio da razão, até porque negar tais valores poderia destruir a razão e inviabilizar a avaliação das tradições e dos costumes (ZARKA, 2013, p. 60-61). Dessa forma, o filósofo vê os princípios ocidentais dos direitos humanos como um “prisma” de análise das práticas culturais externas a essa tradição.

Yves Zarka realiza também uma crítica à chamada discriminação positiva, definida como “a atribuição de direitos diferenciados a comunidades específicas” (ZARKA, 2013, p. 61), arguindo que poderia gerar uma sociedade de discriminação e a instauração de uma influência comunitária sem alternativa aos indivíduos. E afirma que “a discriminação positiva, sob as vestes de generosidade, é uma falsa solução: ela consiste em mudar de lugar a dificuldade ao invés de resolvê-la” (ZARKA, 2013, p. 61-62). Zarka, assim, vê o reconhecimento jurídico das diferenças culturais, defendido por Taylor, como uma perpetuação indefinida das desigualdades que se pretende suprimir. Para tanto, utiliza, assim como o pensador canadense, o exemplo das cotas na universidade, em que vê “a fonte de uma nova opressão para aqueles que não são considerados como beneficiários, os quais correriam o risco de serem sempre considerados como admitidos não em virtude do mérito pessoal, mas sim por uma pertença comunitária” (ZARKA, 2013, p. 62).

Com relação à teoria da cidadania multicultural de Kymlicka, Zarka questiona, num primeiro momento, se a atribuição de direitos a comunidades específicas não lhes daria força para constituir uma forma ao menos embrionária de autogoverno (ZARKA, 2013, p. 154). A preocupação de Zarka deriva da impossibilidade de se admitir que a cidadania multicultural sirva de via de reconhecimento de direitos, pois ela impõe, assim como na teoria de Taylor, uma sociedade de discriminação contrária aos princípios fundamentais das democracias liberais e constitucionais (2013, p. 154-155). Assim, Zarka afirma que “deve-se reconhecer a legitimidade das diferenças culturais, mas sob a condição de que não se questione os princípios democráticos” (ZARKA, 2013, p. 155).

Por fim, Yves Zarka (2013, p. 163) aduz que não é possível assegurar a legitimidade das diferenças culturais de outra forma que não seja fundamentando-as em direitos individuais, invocando a noção clássica de direito subjetivo que funcionaria como garantia de que os direitos culturais não ultrapassariam os princípios democráticos. Zarka (2013, p. 168) entende como desnecessária a proteção de conteúdos culturais determinados e defende que os indivíduos possam acessar livremente a construção cultural que melhor lhes couber, estando assegurada também a possibilidade de eles se deixarem levar por construções culturais que não sejam as suas, ou não se envolverem com o seu contexto social.

As limitações da teoria do multiculturalismo são, no entanto, apontadas pelos próprios defensores das políticas de reconhecimento. Charles Taylor, primeiramente, ainda que defenda o 
cabimento das suas políticas de reconhecimento dentro do escopo do Estado liberal, afirma que "o liberalismo não é um ponto de encontro possível para todas as culturas, mas é, por um lado, a expressão política de uma série de culturas e, por outro, é extremamente incompatível com outras” (TAYLOR, 1998, p. 82). O autor invoca o islamismo como exemplo, por não haver a dissociação entre religião e política, e salienta que o liberalismo tem a sua base oriunda do cristianismo, o que o leva a apontar que o Estado liberal não pode, nem deve ser neutro culturalmente, haja vista que se caracteriza como um “credo combatente” (TAYLOR, 1998, p. 83). Kymlicka, por sua vez, afirma que os negros não se encontram como membros nem de um Estado multicultural, nem de um Estado poliétnico, o que é extremamente problemático para estudar o reconhecimento em países como o Brasil, local em que, mesmo sendo parte considerável da população, as minorias carecem do mesmo reconhecimento que as "minorias nacionais" que o autor defende. Ademais, sobre a forma liberal de reconhecimento das minorias, Werle e Costa (1997, p. 163) afirmam que

É importante observar que a forma liberal de reconhecimento da pertença cultural e dos direitos às minorias dedica pouca atenção à particularidade das culturas em questão. As diferenças não são em si mesmas valorizadas. O que importa é que cada fim ou valor compartilhado que caracteriza a vida cultural de um grupo ou comunidade esteja sujeito à avaliação dos indivíduos autônomos, os quais estão aptos a afirmar ou rejeitar qualquer valor particular, sem com isso correr o risco da perda de direitos ou recursos.

No caso dos povos indígenas, Bonilla Maldonado (2011, p. 571) destaca que o liberalismo multicultural, aliado a um modelo antropológico indigenista, criou uma visão essencialista e homogênea dos povos indígenas, sendo incapaz de dar conta da diversidade que existe dentro de tais coletividades e do caráter contingente da população indígena. Para o professor colombiano, tal modelo projeta os povos indígenas como presentes em um território ancestral rural e uma cultura tradicional estritamente ligada àquele território, o que impossibilita o acesso a direitos culturais para grupos que não preencham tais características, como os indígenas que ocupam espaços urbanos, por exemplo (BONILLA MALDONADO, 2011, p. 571).

Por fim, Rodolfo Stavenhagen (2010, p. 69), ao apresentar sua caracterização tridimensional do multiculturalismo, pugna por criticar o discurso multicultural de direitos humanos. Isso porque, conforme o autor, o multiculturalismo se apresenta em três formas, a saber: a) em escala planetária, o multiculturalismo se caracteriza como a divisão do mundo em um grande número de povos, nações, etnias, culturas e civilizações, dependendo dos critérios de definição utilizados e das preferências de quem realiza esta classificação, sendo, por conta disso, na maior parte das vezes, heteronômica; b) no âmbito dos Estados nacionais, em que geralmente os conflitos etnopolíticos e culturais são mais notados, o problema fundamental do multiculturalismo é que a concepção hegemônica e amplamente 
estendida do Estado nacional monoétnico não corresponde à heterogeneidade cultural da maioria dos países do mundo, sendo tal forma de Estado incapaz de vencer os conflitos culturais; e c) ao nível local (família, bairro, comunidade), em que as relações multiculturais podem se fortalecer ou se romper, provocando conflitos, gerados por preconceito e discriminação contra uma determinada raça ou etnia (STAVENHAGEN, 2010, p. 74).

Contudo, sociedades plurais, como a latino-americana, foram a tônica da realidade social, e o discurso que pressupunha uma igualdade fática entre sujeitos humanos não deu conta de tratar as diferenças de demandas advindas de grupos profundamente diferenciados ${ }^{3}$.

Entre esses grupos, os movimentos sociais dos afrodescendentes no Brasil e na Colômbia se destacaram - do final dos anos 60 até o começo dos anos 90 - por suas mobilizações sociais e ativismo acadêmico-político. Esse ativismo lhes permitiu estabelecer relações estratégicas com seus congêneres afro-norte-americanos. Assim, não somente as mobilizações por direitos civis, nos Estados Unidos, estavam em seu ápice, mas também o discurso multiculturalista passava do “ámbito meramente académico a adquirir una creciente influencia en la opinión pública” (GUNTER, 2005, p. 30).

Dessa maneira, os movimentos afro-brasileiros e afro-colombianos se apropriaram das ferramentas teóricas do multiculturalismo norte-americano (a diferença cultural), para forjar “essencialismos estratégicos”4 (MOSQUERA, 2007, p. 214) e reivindicar uma identidade cultural diferenciada que lhes permitisse, portanto, reclamar seus direitos. Como resultado dessas lutas, a nova Constituição da Colômbia (1991) definiu este país sul-americano como “pluriétnico e multicultural”,

\footnotetext{
${ }^{3}$ É importante referir que Boaventura de Sousa Santos defende uma concepção antiliberal de multiculturalismo, que incorpora elementos importantes da noção de interculturalidade a seguir expostas, e é profundamente ciente das diferentes críticas dirigidas ao multiculturalismo (tanto em termos descritivos quanto críticos). O autor considera que a palavra "generalizou-se como modo de designar as diferenças culturais em um contexto transnacional e global" e que "pode continuar a ser associada a conteúdos e projetos emancipatórios e contra-hegemônicos ou a modos de regulação das diferenças no quadro do exercício da hegemonia nos Estados-nação ou em escala global”. Para o pensador português, "as versões emancipatórias do multiculturalismo baseiam-se no reconhecimento da diferença e do direito à diferença e da coexistência ou construção de uma vida em comum além de diferenças de vários tipos” (SOUSA SANTOS, 2003, p. 33). Santos fala de um multiculturalismo policêntrico como estratégia no plano da produção do conhecimento sobre iniciativas e movimentos emancipatórios em torno da redistribuição e do reconhecimento, baseada no duplo pilar da sociologia das ausências e na teoria da tradução. Tais pilares constituem, segundo Santos, recursos para evitar que as práticas emancipatórias reproduzam concepções e preocupações eurocêntricas. O multiculturalismo policêntrico irá basear-se no reconhecimento de que todas as culturas devem perceber as limitações das suas próprias perspectivas, na igualdade fundamental de todos os povos em termos de status, inteligência e direitos, na descolonização das representações e das relações de poder desiguais entre povos e entre culturas (SOUSA SANTOS, 2003, p. 42).

${ }^{4}$ Citando Spivak, Claudia Mosquera (2007, p. 214) explica os "essencialismos estratégicos" como "solidaridades temporales dirigidas a la acción social, por medio de los cuales aceptan de manera transitoria una posición esencialista en cuanto a sus identidades para poder actuar como bloque".
} 
enquanto que no Brasil, ao fim dos anos 90, ganhou muita força o debate sobre as “ações afirmativas” ou "políticas de cotas".

Não obstante, pode-se asseverar que o multiculturalismo, na América Latina, surgiu para descrever e atender o problema das identidades e/ou culturas diferenciadas que existem no centro das sociedades latino-americana e caribenha. Assim, chegou-se à concessão de propostas políticas de regulação e reconhecimento de direitos para grupos vulneráveis e minoritários, sem se desconectar dos pilares discursivos ocidentais dos direitos humanos; isto é, o paradigma liberal-individualista da modernidade.

Por conta disso, a forma liberal de reconhecimento das minorias não é bastante, por si só, para promovê-las, pois não o faz a partir da valorização simétrica de suas particularidades e características intrínsecas, algo que se dá pela característica ainda ocidentalizada, eurocentrada que inclusive o multiculturalismo de matriz comunitária apresenta. Portanto, faz-se necessário analisar perspectivas que vão além dos limites do Estado liberal moderno. É essa a proposta da interculturalidade, que será analisada a seguir.

\section{A INTERCULTURALIDADE ${ }^{5}$ : UMA RESPOSTA DESCOLONIAL AOS DISCURSOS OCIDENTAIS DE DIREITOS HUMANOS}

Antes de tudo, o paradigma da interculturalidade requer uma análise inicial das várias definições de cultura. Para Ansion (2007, p. 38-39), cultura consiste no modo habitual e compartilhado de fazer as coisas, desde a forma de se vestir, o modo de andar, de conversar, de trabalhar, de cozinhar, etc. Assim, o professor peruano vê a cultura como o modo de se relacionar com os demais seres humanos, com os seres da natureza, com os seres sagrados e com si mesmo (ANSION, 2007, p. 39). Aduz Ansion (2007, p. 39):

El relacionarse con el mundo en la cultura implica construir un mundo de significaciones compartidas por un grupo humano en un proceso histórico. La cultura es, en ese sentido, un modo de conocer, un modo de apropiarse el mundo, un modo de producir símbolos en respuesta a los múltiples retos planteados a lo largo del tiempo por el medio natural y social en el que se vive. Y, a lo largo del tiempo, la cultura es dinámica, se transforma en su relación con los problemas planteados.

\footnotetext{
${ }^{5}$ Não confundir com o conceito de transculturalidade, cunhado pela linguista Zilá Bernd (2005), que ainda é de menos uso pelos pesquisadores da área na América Latina, motivo pelo qual se escolheu trabalhar com o conceito de interculturalidade, que se encontra mais consolidado.
} 
Todavia, o sociólogo peruano alerta que a cultura não existe senão por intermédio dos indivíduos que a incorporaram e lhe compartilham, pois ela não pode ser compreendida como uma essência eterna que é totalmente incomunicável (ANSION, 2007, p. 40).

$\mathrm{Na}$ visão do antropólogo norte-americano Clifford Geertz, a cultura não deve ser compreendida como um complexo de padrões comportamentais, como costumes, usos, tradições, mas sim, como um "conjunto de mecanismos de controle”, como planos, receitas, regras, que governem o seu comportamento (GEERTZ, 2008, p. 33). Isso se dá, conforme aduz Geertz, pois “o homem é precisamente o animal mais desesperadamente dependente de tais mecanismos de controle, extragenéticos, fora da pele, de tais programas culturais, para ordenar seu comportamento”. Assim, fica inequívoca a tese do antropólogo norte-americano de que “a cultura não é um poder, algo ao qual podem ser atribuídos casualmente os acontecimentos sociais, os comportamentos, as instituições ou os processos; ela é um contexto, algo dentro do qual eles podem ser descritos de forma inteligível — isto é, descritos com densidade” (GEERTZ, 2008, p. 11).

Visando enfrentar os processos de exclusão perpetrados pela modernidade/colonialidade, e levando em consideração o significado de cultura e sua consequente diversidade, surge a proposta da interculturalidade, que, segundo Walsh, não se confunde com o multiculturalismo, pois

\begin{abstract}
Mientras que el multiculturalismo sustenta la producción y administración de la diferencia dentro del orden nacional [liberal] volviéndola funcional a la expansión del neoliberalismo, la interculturalidad entendida desde su significación por el movimiento indígena, apunta cambios radicales a este orden. Su afán no es simplemente reconocer, tolerar ni tampoco incorporar lo diferente dentro de la matriz y estructuras establecidas. Por el contrario, es implosionar desde la diferencia en las estructuras coloniales del poder como reto, propuesta, proceso y proyecto; es hacer reconceptualizar y re-fundar estructuras que ponen en escena y en relación equitativa lógicas, prácticas y modos culturales diversos de pensar, actuar y vivir. Así sugiere un proceso activo y permanente de negociación e interrelación donde lo propio y particular no pierdan su diferencia, sino que tengan la oportunidad y capacidad para aportar desde esta diferencia a la creación de nuevas comprensiones, convivencias, colaboraciones y solidaridades. Por eso la interculturalidad no es un hecho dado sino algo en permanente camino, insurgencia y construcción. (WALSH, 2008, p. 141)
\end{abstract}

Ainda sobre as diferenças que marcam a interculturalidade em referência ao multiculturalismo, Walsh (2007, p. 55) pontua que os prometidos reconhecimento e tolerância multiculturais em relação aos outros não somente mantêm a desigualdade social, como deixam intacta a estrutura social e institucional que constrói, reproduz e mantém essas desigualdades. A interculturalidade, enquanto projeto, não se limita a propor tolerância porque não está comprometida com o Estado liberal, senão com a própria refundação do Estado por meio do diálogo intercultural articulado a partir da sociedade, e não o contrário, como prevê o multiculturalismo (WALSH, 2008, p. 142). 
Walsh (2012, p. 63) cinde a interculturalidade em três perspectivas distintas, quais sejam, uma relacional, uma funcional e uma crítica. A perspectiva relacional faz referência, de forma geral, ao contato e intercâmbio entre culturas, ou seja, entre pessoas, práticas, saberes, valores e tradições culturais distintas, algo que sempre ocorreu na América Latina, especialmente após sua colonização, por força da diversidade cultural. Porém, tal perspectiva é ineficaz, pois oculta ou minimiza a conflitividade e os contextos de poder nos quais as relações interculturais acontecem, bem como deixa a interculturalidade apenas no âmbito das relações, olvidando-se das estruturas sociais que as pautam, e que, em certa medida, as inviabilizam (WALSH, 2012, p. 63-64).

A segunda perspectiva da interculturalidade é a funcional, em que a interculturalidade "se enraíza en el reconocimiento de la diversidad y diferencia cultural con metas hacia la inclusión de la misma al interior de la estructura social establecida” (WALSH, 2012, p. 64). Essa perspectiva em muito se assemelha com as políticas de reconhecimento do multiculturalismo, pois a interculturalidade, aqui, seria "funcional” ao sistema vigente, não atacando as desigualdades sociais e culturais, muito menos questionando as regras do sistema, sendo assim, perfeitamente compatível com a lógica liberal-individualista.

A terceira, e mais importante, para Walsh, é a crítica, cujo ponto nevrálgico é o problema estrutural-colonial-racial imposto pela modernidade/colonialidade, bem como sua ligação ao capitalismo (WALSH, 2012, p. 66). A interculturalidade crítica questiona, de forma profunda, a lógica irracional e instrumental do capitalismo, e aponta para a construção de novas sociedades, de um novo ordenamento social (WALSH, 2012, p. 66). Dessa maneira, a interculturalidade crítica não é posta, mas é algo por construir; é projeto que aponta para a transformação das estruturas, condições e dispositivos de poder que mantêm a desigualdade, a racialização, a subalternização e a inferiorização de seres, saberes, lógicas e racionalidades de vida (WALSH, 2012, p. 67). Em Walsh (2007, p. 58), a interculturalidade é um conceito que faz visível a diferença colonial e questiona e modifica a colonialidade do poder, na medida em que se propõe como um paradigma “outro” e oferece um caminho para pensar a partir da diferença e através da descolonização e da construção de uma sociedade radicalmente distinta:

Interculturalidad representa una lógica, no simplemente un discurso, construido desde la particularidad de la diferencia. Una diferencia, en la terminología de Mignolo, que es colonial, que es la consecuencia de la pasada y presente subalternización de pueblos, lenguajes y conocimientos. Esta lógica, en tanto parte desde la diferencia colonial y, más aún, desde una posición de exterioridad, no queda fijada en ella sino que más bien trabaja para transgredir las fronteras de lo que es hegemónico, interior y subalternizado. Dicho de otro modo, la lógica de la interculturalidad compromete un conocimiento y pensamiento que no se encuentra aislado de los paradigmas o estructuras dominantes; por necesidad (y como un resultado del proceso de colonialidad) esta lógica "conoce" esos paradigmas y 
estructuras. Y es a través de ese conocimiento que se genera un conocimiento "otro". Un pensamiento "otro" que orienta el programa del movimiento en las esferas política, social y cultural, mientras opera afectando (y descolonizando), tanto las estructuras y paradigmas dominantes como la estandarización cultural que construye el conocimiento "universal” de Occidente. (WALSH, 2007, p. 51)

Ansion (2007, p. 41) define a interculturalidade, inicialmente, num sentido descritivo; antes de ser um projeto, constitui-se como relações interculturais que existam de fato, que sejam realmente existentes. Para ele, “cuando se encuentran grupos de orígenes culturales distintos se produce aprendizaje - y aprendizaje de ambas partes.” (ANSION, 2007, p. 41) Nesse contexto, segundo o autor, há difusão e incremento de tecnologias, circulação de ideias e relatos que vão se tecendo até que as visões de mundos de uns e outros se influenciem e se transformem (ANSION, 2007, p. 42). Ansion segue a análise da interculturalidade “de fato” assinalando que, num primeiro momento, ela busca centrar-se na análise das formas pelas quais as relações mútuas entre as culturas acontecem, mas não se destina tão somente a isso. Na visão do professor peruano,

Si reconocemos que cualquier cultura es el producto, entre otras cosas, de una larga historia
de intercambios, el concepto de interculturalidad llegaría prácticamente a identificarse con
el de cultura y, por tanto, se volvería inútil y redundante. Por ello, proponemos reservarlo
para señalar situaciones de influencias mutuas particulares: aquellas en las que grupos
culturalmente diferentes se ven obligados por las circunstancias a convivir, a compartir
espacios geográficos y sociales comunes de modo cotidiano, permanente, duradero,
intensivo. Esta situación se ha dado, por ejemplo, en la España de moros, cristianos y judíos
y se dio, de modo mucho más general, en las sociedades del Mediterráneo. También se daba
en los andes prehispánicos y siguió dándose, en un contexto ciertamente muy distinto, luego
de la invasión española. Basta mirar los grandes cambios actuales producidos por las
migraciones internacionales masivas para constatar que el mundo se está volviendo, en ese
sentido, cada vez más intercultural. (ANSION, 2007, p. 42)

A segunda acepção de interculturalidade, na análise de Ansion, é no sentido de projeto, que se define, inicialmente, como um "processo de convivência em paz” (ANSION, 2007, p. 43), o que difere de outras concepções, como a já apresentada "difícil tolerância” de Yves Zarka. Ansion vê o projeto intercultural como sendo a luta por reconhecimento das mais diversas culturas, e, sobretudo, como uma forma de enfrentamento a todas as formas de desprezo e marginalização presentes tanto na vida cotidiana, quanto nas instituições do Estado (ANSION, 2007, p. 44). Assim, o primeiro ponto de um projeto intercultural consistiria em "trabajar por la creación de condiciones de mayor equidad para los grupos subordinados. Esto significa promover concretamente el respeto por el otro cultural, especialmente por aquel que ha sido despreciado” (ANSION, 2007, p. 44).

Mas esse respeito pelo outro deve permitir que se leve a sério as outras culturas, dando às pessoas que lhe compõem a oportunidade de desenvolver sua interação com as demais formas de 
cultura, o que só é possível, para o professor peruano, se as culturas tiverem status público (ANSION, 2007, p. 44-45).

A interculturalidade também foi analisada pelo pesquisador peruano Fidel Tubino, que, assim como Juan Ansion, enxerga nela uma face descritiva e uma proposta ético-política (TUBINO, 2002, p. 74). Para Tubino (2002 p. 74-75), a definição descritiva da interculturalidade concerne às distintas formas de relação entre culturas que encontramos de fato na vida social, como a aculturação, a miscigenação, o sincretismo, a hibridização, que revelam a complexidade das relações sociais. Já a dimensão ético-política é colocada pelo peruano como um “dever-ser possível”, que se distingue do multiculturalismo por substituir o fundamento da tolerância pelo fundamento do diálogo (TUBINO, 2002, p. 75). Assim, conforme Fidel Tubino (2002, p. 75-76),

\begin{abstract}
La interculturalidad como propuesta ético-política presupone el multiculturalismo, es decir, la reducción de las relaciones asimétricas entre las culturas. Podemos plantearlos también en términos conceptuales y decir que la interculturalidad presupone a veces el multiculturalismo así como dialogo intercultural presupone la tolerancia. La tolerancia negativa consiste en no hacer de una creencia propia una condición absoluta de la convivencia. Se trata de aprender a restringir la función de nuestras creencias. La tolerancia positiva presupone la tolerancia negativa y consiste en algo adicional: Comprender al otro. Es decir, intentar colocarse en su lugar, entenderlo desde su visión del mundo y su jerarquía de valoraciones. Comprender al otro es también percibirme desde su mirada: la tolerancia positiva o comprensiva es la condición necesaria del diálogo intercultural es la autorecreación transcultural: regresar a nosotros después de habitar las miradas de otros, ponernos experencialmente en perspectiva, transformarnos recíprocramente. Para decirlo en términos más específicos, se trata de propiciar la apropiación selectiva y crítica de lo que mi interlocutor cultural me ofrece, de asumir una actitud activa que me permita reestructurar lo propio, autotransformarlo reflexivamente, escogerlo y reinventarlo.
\end{abstract}

Além das distinções já apresentadas no tocante à interculturalidade, vale acrescentar a visão de Xavier Albó, que, inicialmente, nivelou a interculturalidade em diversas escalas que poderiam separar uma interculturalidade negativa de outra positiva (ALBÓ, 2012, p. 9). Assim, o diálogo intercultural, na concepção de Albó, poderia ser cindido em cinco níveis, quais sejam, a) a destruição de uma das partes; b) a diminuição de uma das partes, por subjugá-la ou por criar dependências que impeçam o seu crescimento; c) limitar as relações, sem um justo motivo para isso; d) simples tolerância, em que os grupos distintos se aguentam sem se prejudicar um ao outro; e) mútuo entendimento e intercâmbio, que leva ao enriquecimento cultural de ambas as partes.

O professor catalão entende que tais níveis podem levar algum tempo para avançar, dada as antropologicamente comprovadas dificuldades num primeiro contato entre grupos sociais distintos, mas, ainda assim, por mais que a relação possa se dar numa conotação negativa, ambas as partes estão se desenvolvendo com o contato, o que é positivo (ALBÓ, 2012, p. 9-10). 
Além disso, Albó desenvolveu a distinção entre microinterculturalidade e macrointerculturalidade, que seriam atinentes aos níveis de complexidade que a interculturalidade pode alcançar (ALBÓ, 2012, p. 10). Nessa distinção, Albó define a microinterculturalidade como a que prevalece nas relações interpessoais, como as entre indivíduos e pequenos grupos, ou entre grupos maiores que habitam uma mesma região, e caracterizou a macrointerculturalidade como aquela que tem efeitos nas estruturas e sistemas da sociedade, própria de grupos e de instituições de alcance social nacional ou maior, como as de educação e comunicação, nas relações internacionais e na confrontação, intercâmbio ou articulação entre sistemas, civilizações e lógicas culturalmente contrapostas (ALBÓ, 2012, p. 10-11).

Na interpretação de Tubino (2002, p. 76), não existe relação de causa e efeito entre essas duas categorias, mas sim, complementaridade e simultaneidade, o que o leva a afirmar que "las políticas de Estado, sin bien son acondicionamientos importantes de las relaciones interpersonales entre personas de culturas diferentes en el espacio micro y contribuyen a estructurarlas, éstas no son resultados de aquéllas” (TUBINO, 2002, p. 76-77). Por fim, Tubino conclui que, tendo em vista os níveis do diálogo intercultural que já apresentamos, tanto no nível macro, quanto no nível micro, as ações transformativas com o intuito de promover a interculturalidade positiva devem ser constantemente impulsionadas (TUBINO, 2002, p. 77).

Vale, ainda, agregar que, para Wolkmer (2006, p. 120), a interculturalidade permite “o reconhecimento de outra cultura jurídica, marcada pelo pluralismo de tipo comunitário-participativo e pela legitimidade construída através das práticas internalizadas de sujeitos sociais”, o que é fundamental para que surja uma nova cultura de direitos humanos, que possa enfrentar a tradição moderna/colonial, e dar voz aos indivíduos e grupos marginalizados e estigmatizados da América Latina.

Portanto, a interculturalidade nos indica um caminho. Um caminho de inclusão, de encontro qualitativo e solidário com o outro diferente, um encontro que deve possibilitar a aceitação do diferente como uma oportunidade de enriquecimento e transformação de ambas as partes. Assim, a via intercultural se coloca como crítica tanto à cultura hegemônica excludente quanto ao multiculturalismo, e se apresenta como um projeto ético-político libertador, renovador e aberto, cujo objetivo inconteste é a busca pela convivência - entre indivíduos e povos ou nações - pacífica. 


\section{CONSIDERAÇÕES FINAIS: DIREITOS HUMANOS NA AMÉRICA LATINA: UM PROJETO INTERCULTURAL?}

Com base no que foi exposto, é inafastável compreender que a América Latina é marcada por profundas assimetrias em termos de garantia de direitos humanos. Seus sujeitos são diversos entre si e essa diversidade, ao contrário de ser valorizada como vetor para a construção de sociedades plurais e solidárias, é usada como fator de hierarquização e menosprezo (veja-se a raiz da inversão ideológica dos direitos humanos, em Hinkelammert). Direitos humanos são violados de forma profundamente seletiva na América Latina, atingindo aqueles a quem o discurso racionalindividualista nega os traços do humano - negros, mulheres, índios, homossexuais.

Dessa maneira, torna-se curto o discurso universalista dos direitos humanos, cujas expressões políticas se encontram no multiculturalismo, pois a despeito de assumir a questão da diversidade cultural, não abre mão do padrão de superioridade moral das sociedades liberaisindividualistas do Ocidente. Esse mesmo discurso alijou diversos indivíduos e grupos estigmatizados dos direitos que lhes seriam inatos, por meio de uma retórica excludente que os transformou em menos humanos, com o argumento da ausência da razão ${ }^{6}$, atribuindo-lhes uma espécie de culpa pela destruição de seus próprios direitos.

Isso mostra que o universalismo dos direitos humanos manipulou de forma cínica um duplo discurso, fazendo com que a concepção de ser humano variasse, conforme se trate do homem branco ou de negros, indígenas e mulheres: o primeiro considerado como ser humano por antonomásia, sendo, portanto, sujeito pleno de direitos; e o segundo grupo visto como menos humanos, e, por conta disso, tendo seus direitos impunemente violados.

O multiculturalismo, por sua vez, embora busque se colocar como uma alternativa à miopia universalista, não consegue dar respostas adequadas à não efetivação dos direitos humanos, pois falha quando predica ingenuamente a coexistência de diversas culturas e raças dentro do marco do Estado liberal, cujos fundamentos ideológicos produziram o mal (a exclusão do diferente, o menosprezo por ele) que o mesmo multiculturalismo quer combater. Os próprios autores do multiculturalismo afirmam que a sua aplicação só é possível num Estado que consiga acolher as diferenças; caso contrário, não haverá possibilidade de efetivação de direitos.

\footnotetext{
${ }^{6}$ Cabe assinalar que, no discurso racional-individualista ocidental, a razão, que é um atributo eminentemente humano, isto é, uma qualidade que possuem todos os seres humanos, foi convertida na racionalidade ocidental; em outras palavras, esta última, que é o desenvolvimento histórico da razão nas culturas da Europa ocidental, foi autocomplacentemente considerada como a "razão universal”. Então, é necessário denunciar e desconstruir aqui a instrumentalização da razão para fins de exclusão e dominação dos povos não ocidentais (MAGALLÓN ANAYA, 2006, p. 22-86). Não obstante, Dussel (1994, p. 22) diria: “no negamos entonces la razón, sino la irracionalidad de la violencia del mito moderno”.
} 
Ademais, o multiculturalismo, por manter a base liberal, não tem capacidade de atingir as particularidades dos grupos marginalizados e estigmatizados pelo mesmo liberalismo. E, além disso, tal discurso não se preocupa com as estruturas de poder que regem as relações entre um grupo e outro, o que torna ineficiente a política de reconhecimento que defende para combater o discurso moderno/colonial dos direitos humanos. Por isso, o respeito pleno aos direitos humanos não se pode efetivar por meio de políticas multiculturais que requerem a subordinação dos grupos tolerados. Sem dúvidas, é possível afirmar que nessas políticas persiste a ideia da inferioridade cultural e étnicoracial dos grupos diferenciados e tolerados e, por conseguinte, sua exclusão e opressão.

Para dar respostas a esses pontos cegos do multiculturalismo, parece-nos imprescindível a proposta da interculturalidade. Como foi apresentado acima, essa proposta tem um grande potencial ético-político para efetivar os direitos humanos: por um lado é crítica, já que desvela a parte inumana da racionalidade moderna/colonial, como produtora de exclusão e discriminação; por outro lado, enquanto projeto, não predica nem a subordinação nem a simples tolerância e/ou reconhecimento do outro, mas, por sua vez, defende encontros e diálogos humanizantes entre as culturas, que possam ser transformadores de indivíduos e grupos, consolidando a busca pela paz social.

Afinal, para a efetivação dos direitos humanos a partir das realidades plurais da América Latina, é indispensável uma crítica incisiva e criativa aos cânones da modernidade/colonialidade. Enfrentar esses cânones significa, por um lado, denunciar as diferentes estruturas institucionais que seguem reproduzindo as relações assimétricas de poder, o racismo e o patriarcado, que tornam perenes as violações massivas de direitos humanos; por outro lado, significa construir uma possibilidade intercultural que rompa precisamente com a lógica moderna/colonial excludente, pois defende essencialmente a humanidade do outro desprezada por essa lógica, pugnando, dessa forma, por um diálogo horizontal e simétrico, em vista de uma sociedade livre, justa, solidária e em paz.

\section{REFERÊNCIAS}

ALBÓ, Xavier. Interculturalidad en el desarollo rural sostenible: el caso de Bolivia. La Paz: Centro de Investigación y Promoción del Campesinado, 2012.

ANDRADE, Alysson. A política de reconhecimento em Charles Taylor. 2013. 209 p. Dissertação (Mestrado em Filosofia) - Faculdade Jesuíta de Filosofia e Teologia, Belo Horizonte, 2013.

ANSION, Juan. La interculturalidad y los desafios de una nueva forma de ciudadanía. In: ANSION, Juan; TUBINO, Fidel (Org.). Educar en Ciudadania Intercultural. Lima: Fondo Editorial de la Pontificia Universidad Catolica del Peru, 2007. p. 37-63. 
ARDAO, Arturo. América Latina y la latinidad. México: CCyDEL-UNAM, 1993.

BERND, Zilá. Estudos canadenses e transculturalismos. In: ALMEIDA, Sandra Regina Goulart (Org.). Perspectivas transnacionais $=$ Perspectives transnationales $=$ Transnational perspectives. Belo Horizonte: ABECAN/Faculdade de Letras/UFMG, 2005. p. 145-154

BOBBIO, Norberto. A era dos direitos. Tradução Carlos Nelson Coutinho. Rio de Janeiro: Elsevier, 2004.

BOBBIO, Norberto. Liberalismo e democracia. 6. ed. São Paulo: Brasiliense, 1998.

BONILLA MALDONADO, Hector. Indígenas urbanos y derechos culturales: los límites del multiculturalismo liberal. Revista Direito GV. São Paulo, v. 7, n. 2, p. 569-604, jul-dez 2011.

BRAGATO, Fernanda Frizzo. Para além do discurso eurocêntrico dos direitos humanos: contribuições da descolonialidade. Novos Estudos Jurídicos - Eletrônica. Itajaí, v. 19, n. 1, p. 201230, jan-abr 2014.

BRAGATO, Fernanda Frizzo. Pessoa humana e direitos humanos na Constituição Brasileira de 1988 a partir da perspectiva pós-colonial. 2009. 350 p. Tese (Doutorado em Direito) - Programa de Pós-Graduação em Direito, Universidade do Vale do Rio dos Sinos, São Leopoldo/RS, 2009.

DUSSEL, Enrique. 1492: El encubrimiento del Otro: hacia el origen del "Mito de la Modernidad". La Paz: Plural Editores, 1994.

DUSSEL, Enrique. Filosofías del sur. Descolonización y Transmodernidad. Ixtapaluca-Estado de México: Akal/Inter Pares, 2015.

ESCOBAR, Arturo. Mundos y conocimientos de otro modo: el programa de investigación de modernidad/colonialidad latinoamericano. Tabula Rasa, Bogotá, p. 51-86, 2003.

GALL, Olivia. Relaciones entre racismo y modernidad: preguntas y planteamientos. In: GALL, Olivia (Coord.) Racismo, mestizaje y modernidad: visiones desde latitudes diversas. México: CEIICH-CRIM/UNAM, p. 63-88, 2007.

GEERTZ, Clifford. A interpretação das culturas. Rio de Janeiro: LTC, 2008.

GONZÁLEZ CASANOVA, Pablo. Sociología de la explotación. Buenos Aires: Consejo Latinoamericano de Ciencias Sociales, 2006.

HINKELAMMERT, Franz. El sujeto y la ley. San José: UNA, 2003.

KYMLICKA, Will. Ciudadanía multicultural: Una teoría liberal de los derechos de las minorías. Barcelona: Paidós, 2010.

MAGALLÓN ANAYA, Mario. Modernidad alternativa: viejos retos y nuevos problemas. México: CCyDEL-UNAM, 2006. 
MIGNOLO, Walter. La idea de America Latina. Barcelona: Editorial Gedisa, 2007.

MOSQUERA, Claudia. Reparaciones para negros, afrocolombianos y raizales como rescatados de la Trata Negrera Transatlántica y desterrados de la guerra en Colombia. In: MOSQUERA, Claudia; BARCELOS, Luiz Claudio (Ed.) Afro-reparaciones: Memorias de la esclavitud y Justicia Reparativa para negros, afrocolombianos y raizales. Bogotá: Universidad Nacional de Colombia, 2007.

QUIJANO, Aníbal; WALLERSTEIN, Immanuel. Colonialidad del poder y clasificación social. In: CASTRO-GÓMEZ, S.; GROSFOGUEL, R. (Ed.). El giro decolonial. Reflexiones para una diversidad epistémica más allá del capitalismo global. Bogotá: Iesco-Pensar-Siglo del Hombre Editores, 2007. p. 93-126.

QUIJANO, Aníbal; WALLERSTEIN, Immanuel. Colonialidade do poder, eurocentrismo e América Latina. In: LANDER, Edgardo (Org.). A colonialidade do saber: eurocentrismo e ciências sociais. Perspectivas latino-americanas. Buenos Aires: Colección Sur Sur, CLACSO, 2005. p. 227-278.

QUIJANO, Aníbal; WALLERSTEIN, Immanuel. La americanidad como concepto, o América en el moderno sistema mundial. Revista Internacional de Ciencias Sociales. Barcelona, vol. XLIV, n 4 , p. 583-593, dez. 1992.

SEEMANN, Jörn. Em busca do lugar de Franz Boas na geografia cultural. Espaço e Cultura. Rio de Janeiro, n. 19-20, p. 7-21, jan-dez 2005.

SOUSA SANTOS, Boaventura de. Reconhecer para libertar: os caminhos do cosmopolitismo multicultural. Rio de Janeiro: Civilização Brasileira, 2003.

STAVENHAGEN, Rodolfo. Multiculturalidad y derechos culturales. In: FERNÁNDEZ, Norma (Org.). Los pueblos originarios: el debate necesario. Buenos Aires: CTA Ediciones, 2010.

TAYLOR, Charles. Multiculturalismo: examinando a política de reconhecimento. Lisboa: Instituto Piaget, 1998.

TENFEN SILVA, Larissa. O multiculturalismo e a política de reconhecimento de Charles Taylor. Novos Estudos Jurídicos. Florianópolis, v. 11, n. 2, p. 319, jul.-dez. 2006.

TUBINO, Fidel. Entre el multiculturalismo y la interculturalidad: mas allá de la discriminación positiva. In: FULLER, Norma (Ed.). Interculturalidad y política: desafios y posibilidades. Lima: Red para el Desarollo de las Ciencias Sociales en el Peru, 2002.

WADE, Peter. Race and Ethnicity in Latin America. London: Pluto Press, 1997.

WALSH, Catherine. Interculturalidad y (de)colonialidad: perspectivas críticas y politicas. Visão Global. Joaçaba, v. 15, n. 1-2, p. 61-74, jan-dez 2012. 
WALSH, Catherine. Interculturalidad y colonialidad del poder. Un pensamiento y posicionamiento “otro” desde la diferencia colonial. In: CASTRO-GÓMEZ, S.; GROSFOGUEL, R. (Ed.). El giro decolonial. Reflexiones para una diversidad epistémica más allá del capitalismo global. Bogotá: Iesco-Pensar-Siglo del Hombre Editores, 2007. p. 47-62.

WALSH, Catherine. Interculturalidad, plurinacionalidad y decolonialidad: las insurgencias políticoepistémicas de refundar el Estado. Tabula Rasa. Bogotá, n. 9, p. 131-152, jul-dez 2008.

WERLE, Denílson Luís; COSTA, Sérgio. Liberais, comunitaristas e as relações raciais no Brasil. Novos Estudos. São Paulo, n. 49, p. 159-178, nov 1997.

WOLKMER, Antônio Carlos. Pluralismo jurídico, direitos humanos e interculturalidade. Revista Sequência. Florianópolis, n. 53, p. 113-128, dez 2006.

ZARKA, Yves Charles. Difícil tolerância: a coexistência de culturas em regimes democráticos. Tradução Anderson Vichinkeski Teixeira. São Leopoldo: Editora Unisinos, 2013.

ZEA, Leopoldo. América en la historia. Madrid: Editorial Revista del Occidente, 1970.

Fernanda Frizzo Bragato Graduada em Direito pela Universidade Federal do Rio Grande do Sul (2002), Mestra em Direito pela Universidade do Vale do Rio dos Sinos - Unisinos (2005), Doutora em Direito pela Unisinos, com período de estágio doutoral na University of London (Birkbeck College) (2009) e pós-doutora pela University of London (School of Law - Birkbeck College) (2012). Atualmente é professora do Programa de Pós-Graduação e Graduação em Direito na Unisinos e Coordenadora do Núcleo de Direitos Humanos da mesma instituição. E-mail: fernandabragato@yahoo.com.br

Vicente de Paulo Barretto Graduado em Direito pela Universidade do Estado da Guanabara (1962). Pós-doutor pela Maison des Sciences de L'Homme, Paris. Livre-docente em Filosofia pela PUCRJ (1976). Professor do Programa de Pós-Graduação em Direito da Unesa; professor do Programa de Pós-Graduação em Direito da Unisinos; decano da Escola de Direito da Unisinos; professor visitante da Faculdade de Direito da Universidade de Coimbra. E-mail: vpbarretto@terra.com.br

Alex Sandro da Silveira Filho Acadêmico dos cursos de Direito e de Filosofia da Unisinos. Bolsista de Iniciação Científica PIBIC/CNPq do Programa de Pós-Graduação em Direito da Unisinos, vinculado ao projeto de pesquisa Os Direitos Humanos no contexto latino-americano: do caráter universal à interculturalidade, coordenado pelo Prof. Dr. Vicente de Paulo Barretto. Membro do Núcleo de Direitos Humanos (NDH) da Unisinos, coordenado pela Prof. ${ }^{a}$ Dr. ${ }^{a}$ Fernanda Frizzo Bragato.E-mail: alexsilveirafilho@yahoo.com

Este trabalho está vinculado ao projeto de pesquisa do CNPq $n^{\circ} 476114 / 2013-6$, aprovado no Edital Universal n 14/2013 (Faixa B - até R\$ 60.000,00), intitulado Os direitos humanos no contexto latino-americano: do caráter universal à interculturalidade, sob a coordenação do Prof. Dr. Vicente de Paulo Barretto. 